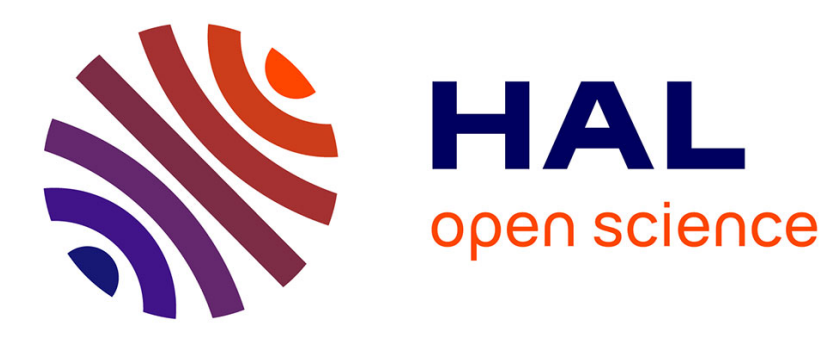

\title{
Preparation and characterization of polytetrafluoroethylene (PTFE)/Thermally Expanded Graphite (TEG) nanocomposites
}

Mounir Sahli, Axel Cablé, Khaled Chetehouna, Smail Hamamda, Nicolas Gascoin, S. Revo

\section{To cite this version:}

Mounir Sahli, Axel Cablé, Khaled Chetehouna, Smail Hamamda, Nicolas Gascoin, et al.. Preparation and characterization of polytetrafluoroethylene (PTFE)/Thermally Expanded Graphite (TEG) nanocomposites. Composites Part B: Engineering, 2017, 124, pp.175-181. 10.1016/j.compositesb.2017.05.046 . hal-01570492

\section{HAL Id: hal-01570492 https://hal.science/hal-01570492}

Submitted on 12 Aug 2017

HAL is a multi-disciplinary open access archive for the deposit and dissemination of scientific research documents, whether they are published or not. The documents may come from teaching and research institutions in France or abroad, or from public or private research centers.
L'archive ouverte pluridisciplinaire HAL, est destinée au dépôt et à la diffusion de documents scientifiques de niveau recherche, publiés ou non, émanant des établissements d'enseignement et de recherche français ou étrangers, des laboratoires publics ou privés. 


\section{Preparation and characterization of polytetrafluoroethylene (PTFE)/Thermally Expanded Graphite (TEG...}

Article in Composites Part B Engineering · September 2017

DOI: 10.1016/j.compositesb.2017.05.046

CITATIONS

0

6 authors, including:

\section{Smail Hamamda}

University of Constantine 1

25 PUBLICATIONS 120 CITATIONS

SEE PROFILE

\section{S. Revo}

National Taras Shevchenko University of Kyiv

49 PUBLICATIONS 51 CITATIONS

SEE PROFILE
READS

11

\section{Nicolas Gascoin}

Institut National des Sciences Appliquées Ce... 107 PUBLICATIONS 489 CITATIONS

SEE PROFILE

Some of the authors of this publication are also working on these related projects: 


\title{
Preparation and Characterization of Polytetrafluoroethylene (PTFE)/Thermally Expanded Graphite (TEG) Nanocomposites
}

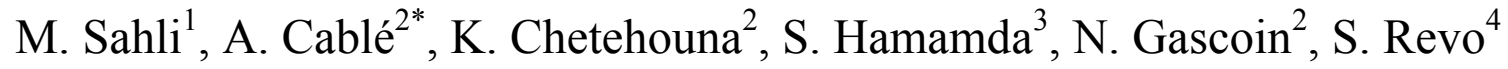 \\ *corresponding author: axel.cable@insa-cvl.fr \\ ${ }^{1}$ Laboratory of Physics and Energy Sciences, Université des Frères Mentouri - Constantine, \\ Algeria \\ ${ }^{2}$ INSA Centre Val de Loire, Laboratoire PRISME - Bourges, France \\ 3 Laboratory of Thermodynamics and Surface Treatment of Materials, University of \\ Constantine 1 - Constantine, Algeria \\ ${ }^{4}$ Taras Shevchenko National University of Kyiv - Kiev, Ukraine
}

\begin{abstract}
In this study, TEG-reinforced polytetrafluoroethylene (PTFE) nanocomposites were prepared. The structural properties of the PTFE/TEG composites were then investigated using X-ray diffraction (XRD) and infrared spectroscopy (FT-IR). Subsequently, the thermal stability, thermal resistance of the composites were studied through differential scanning calorimetry (DSC) and thermo-gravimetric analysis (TGA). The XRD results allowed to report a high degree of dispersion of the TEG inside of the PTFE matrix. Moreover, milling at high temperature was found to enhance the dispersion of the TEG inside of the polymer matrix. Furthermore, the results revealed an increase of the glass-transition temperature when using an increased concentration of TEG. This result confirms that the degradation of the TEG/PTFE nanocomposite occurs at a higher temperature with a greater TEG loading. These finds give an indication of the potential of TEG to improve the thermal properties and durability of PTFE, for instance with application in the field of aeronautics.
\end{abstract}

Keywords : Nanocomposites, Physical properties, Thermal properties 


\section{Introduction}

Polymer nanocomposites are multiphase materials obtained by dispersing a filling agent with dimension in the order of nanometers into a polymer matrix. Various materials are commonly used as nanofillers, such as clay, silica, carbon-based materials. The resulting polymer nanocomposite displays enhanced properties, for instance in terms of rigidity, strain resistance, electrical conductivity, etc. In this context, a significant increase of interest has been observed in the last decade in the field of black carbon, carbon nanotubes and expanded graphite (EG) used as nanofillers of polymer materials [1][2]. The present study focuses on EG as nanofiller, and in particular EG obtained by thermal treatment, ie. Thermally Expanded Graphite (TEG). The latter has several advantages, including availability at relatively low cost and ease of production [3]. Numerous properties can be enhanced by adding EG as nanofiller in a polymer matrix. These improvements are well documented in the literature in the context of various applications. [4-7] have reported an improvement of the oil absorption properties by using EG mixed with magnetic sorbents. This is particularly relevant in the context of environmental issues, for instance oil spill remediation, or water purification [8]. The potential of EG has also been extensively studied in the field of energy storage in buildings, in particular regarding Phase Change Materials and thermal conductivity of building materials [9-13]. The electrical conductivity of polymers is generally low. Adding nanofillers in an amount that exceeds the percolation threshold allows to improve their electrical and thermal conductive properties for application in the field of electronics [14-18]. In this context, the potential of EG to improve the performance of Fuel cells has been reported by [19-21]. Finally, [22-25] have studied the potential of EG to improve the durability and mechanical properties of polymer materials, while [26][27] have observed an increase of flame retardation properties. Hence, numerous studies have been carried out regarding the preparation and 
characterization of polymer nanocomposites. They differ by the studied materials (type of polymer and nanofiller), the preparation method for the nanocomposites, and the characterization techniques involved. Commonly studied polymers include PET [28], Epoxy [22][23], PEDS [25] and PTFE [24, 29-34]. In the present study, TEG was used as reinforcing nanofiller in a fluoroplastic (PTFE) polymer matrix, whose general formula is: $-[-\mathrm{CF} 2-\mathrm{CF} 2-$ ]$_{\mathrm{n}}$. PTFE, owing to its' qualities of low friction and non-reactivity, is used in a wide array of applications in the industry - from wiring in aerospace, machinery lubricant, to non-stick coating for cookware. PTFE and TEG were chosen to study the possibility of increasing the functional characteristics of PTFE, including enhancing its kinetic characteristics, elastic limit, wear resistance, etc. In fact, various studies have been carried out regarding nanocomposites based on PTFE and carbon-based nanofillers [24, 29-36]. However, these studies focused mainly on the potential of carbon nanofillers to improve the mechanical and tribological properties of PTFE. They concluded towards an enhanced durability and increased resistance to wear of the obtained nanocomposites compared to raw PTFE. In this context, the aim of the present work was to further assess the potential of TEG as filling agent for PTFE. In particular, the focus was put on the impact of TEG on the structural and on the thermal properties and degradation process of the resulting PTFE/TEG nanocomposites. The influence of the conditions when preparing the nanocomposites was as well considered. In the present document, the procedure for preparing the TEG and PTFE/TEG nanocomposites is first presented, followed by a description of the characterization methods employed and associated results.

\section{Experimental procedure}

\subsection{Preparation of TEG}


The raw material used for the preparation of TEG was natural graphite, which was oxidized by sulfuric acid. The latter enables to optimize the expansion volume of the graphite after thermal treatment [37]. Graphite oxide was then exposed to thermal treatment in the apparatus

(Fig. 1), at a temperature of $\sim 1000^{\circ} \mathrm{C}$ during 1 minute, which gives the best results in terms of expansion volume according to [38]. An apparatus for the production of TEG has been developed in the context of the present study. The apparatus is presented on Figure 1 ; it allows the preparation of TEG at a rate of $1.5 \mathrm{~kg} / \mathrm{h}$. A gas flow rate valve is used to control the combustion and maintain the combustion chamber at the desired temperature. The developed apparatus has numerous advantages: its design is technologically relatively simple and it can be easily carried around. This makes it highly relevant for instance for applications requiring onsite production of TEG, such as oil spill remediation. The aspect of the TEG obtained with the apparatus and used for the samples is depicted on Figure 2, as well as the microstructure of the TEG obtained by scanning electron microscope.

Figure 1. View of the apparatus for direct production of TEG at a rate of $1.5 \mathrm{~kg} / \mathrm{h} .1$ : Combustion chamber. 2: Container for graphite supply to the combustion chamber. 3: Raw graphite transport system. 4: Gas flow rate control valve. 5: TEG outlet. 6: Gas bottle. 7: Power supply.

Figure 2. Aspect of the TEG produced with the experimental device: macroscopic view (left), microstructure (middle) obtained by scanning electron microscope; pure PTFE (right).

\subsection{Preparation of PTFE/TEG nanocomposites}

The PTFE/TEG nanocomposite samples were prepared by manual milling. An analytical balance was used to weight the PTFE and TEG, which were then sieved and mixed together 
by vigorous manual milling in a mortar during approximately one hour. Three different mass fractions of TEG were considered for the samples: $2.5 \mathrm{wt} \%$, $5 \mathrm{wt} \%$, and $10 \mathrm{wt} \%$. These values were chosen such as to obtain a composite material in the percolation threshold. In addition, two different thermal pre-treatment were considered, ie. milling at ambient temperature (around $23^{\circ} \mathrm{C}$ ), and milling at a temperature of $160^{\circ} \mathrm{C}$. For the samples milled at a temperature of $160^{\circ} \mathrm{C}$, the PTFE and TEG were first mixed in a heated crucible until the mixture reached the temperature of $160^{\circ} \mathrm{C}$ (sample temperature measured by IR thermometry). Then, the mixture was milled in a mortar in a similar manner than for the samples obtained at ambient temperature. Thus, a total of 6 samples were obtained and characterized. The aspect of the PTFE used for the samples is depicted on Figure 2.

\subsection{Characterization methods}

The following methods have been used in order to study the morphological and thermal properties of the samples. X-ray diffraction (XRD) of the composites was carried out using a XPERT-PRO diffractometer system, with $\mathrm{CuKa}$ radiation at $45 \mathrm{kV}$ and $40 \mathrm{~mA}$ in order to assess the structural properties of the PTFE/TEG nanocomposites. In particular, XRD allowed to follow the impact of the addition of TEG on the crystallinity of the obtained nanocomposite material. The measurements were carried out at a temperature of $25^{\circ} \mathrm{C}$, with a copper anode. The sample was examined within the interval $2 \theta=(20 \ldots 70)^{\circ}$. The Fourier Transform InfraRed (FT-IR) spectroscopy measurements were conducted using a Jasco FT/130 IR-6300 (Jasco Analytical Instruments, Easton, MD, USA) instrument to further study the structure of the material. The investigation was carried out in the frequency range of $(600 \ldots 4000) \mathrm{cm}^{-1}$, with a resolution of $4 \mathrm{~cm}^{-1}$. The scanning speed was $2 \mathrm{~mm} / \mathrm{sec}$. The ATR method was used, with a TGS detector. Thermogravimetric analysis (TGA) and Differential Scanning Calorimetry (DSC) measurements were performed in order to study the thermal properties of 
the samples. They were performed simultaneously for all samples, with a Jupiter STA 449 F3 calorimeter by NETZSCH (NETZSCH, Selb, Germany). An $\mathrm{Al}_{2} \mathrm{O}_{3}$ crucible was used. The samples were studied in the temperature range $(24 \ldots 320)^{\circ} \mathrm{C}$, at a heating rate of $10 \mathrm{~K} / \mathrm{min}$. All TGA-DSC measurements were carried out under an Argon atmosphere with flow rate of $20.0 \mathrm{ml} / \mathrm{min}$. The mass of the studied samples were measured as follows - for the samples milled at $\mathrm{T}=23^{\circ} \mathrm{C}: 33.95 \mathrm{mg}$ (10wt \% TEG) $29.10 \mathrm{mg}$ (5wt \% TEG) 35.86 (2.5wt \% TEG). For the samples milled at $\mathrm{T}=160^{\circ} \mathrm{C}: 25.10 \mathrm{mg}$ (10wt \% TEG) $30.05 \mathrm{mg}$ (5wt \% TEG) $27.22 \mathrm{mg}$ (2.5wt \% TEG).

\section{Results and discussion}

\subsection{Structural characterization}

\subsubsection{XRD}

The structural properties of the PTFE/TEG nanocomposite was first investigated using XRD. The XRD pattern of the PTFE/TEG samples is shown on Figure 3, while the corresponding measured values are presented in Table 1 and Table 2. Two broad peaks can be observed at $2 \Theta$ around $26.5^{\circ}$ and $54.6^{\circ}$. These peaks correspond to the (002) and (004) peaks, which are respectively the X-ray diffraction of carbon in the PTFE matrix, and also in TEG. The XRD patterns reveal that a high dispersion of the TEG nanofillers within the PTFE matrix was achieved. In fact, the peak at $2 \Theta$ around $54.6^{\circ}(004)$ is barely noticeable and its relative intensity is low for all samples (see Table 1 and Table 2). This behavior gives an indication that milling allows an appropriate dispersion of TEG, and is thus an acceptable method for the preparation of PTFE/TEG nanocomposites. The effect of milling temperature on the TEG dispersion is noticeable as well. For a given TEG concentration, the relative intensity of the (004) peak diminished when milling at $\mathrm{T}=160^{\circ} \mathrm{C}$ compared to milling at $\mathrm{T}=23^{\circ} \mathrm{C}$; see Table 1 and Table 2. This trend was observed for all samples. Thus, increasing the milling 
temperature improved the dispersion of TEG within the PTFE matrix. It can also be observed from the intensity of the (002) peaks that the crystallinity rate was enhanced when the TEG concentration increased, and that it was particularly high for the $10 \%$ TEG sample. Furthermore, it is possible to determine the size of the crystals which compose the sample by applying the Scherrer relation to the different X-ray diffraction peaks [39]. The width of the (002) peaks is quite important for all samples, which is an indication of the presence of crystals of small size in the samples (here in the range of 47 to $55 \mathrm{~nm}$ ) according to Scherrer's equation [39], see Table 1 and Table 2.

Figure 3. XRD pattern of the PTFE/TEG nanocomposite at different percentage of TEG mass fraction for the samples milled at $\mathrm{T}=23^{\circ} \mathrm{C}$ (ambient temperature) and at $\mathrm{T}=160^{\circ} \mathrm{C}$.

Table 1. XRD results for the samples milled at $\mathrm{T}=23^{\circ} \mathrm{C}$

Table 2. XRD results for the samples milled at $\mathrm{T}=160^{\circ} \mathrm{C}$

\subsubsection{FTIR}

The structure of the samples was further investigated using Fourier Transform Infra-Red spectroscopy. The obtained results are presented on Figure 4. The dominant IR bands obtained were $1123 \mathrm{~cm}^{-1}, 966 \mathrm{~cm}^{-1}, 1194 \mathrm{~cm}^{-1}, 585 \mathrm{~cm}^{-1}, 661 \mathrm{~cm}^{-1}, 1283 \mathrm{~cm}^{-1}$ and $2358 \mathrm{~cm}^{-1}$. Based on the general formula of PTFE: $-[-\mathrm{CF} 2-\mathrm{CF} 2-]_{\mathrm{n}}$ and on the literature, the following assignments have been made: $\mathrm{CF}_{3}$ symmetric stretching $\left(1123 \mathrm{~cm}^{-1}\right)$ [40], $\mathrm{CH}$ out-of-plane deformation of trans double bonds $\left(966 \mathrm{~cm}^{-1}\right)$ [37], $\mathrm{CF}_{2}$ stretching $\left(1194 \mathrm{~cm}^{-1}\right)$ [40][42][43], CF stretching $\left(1283 \mathrm{~cm}^{-1}\right)$ [43], $\mathrm{CF}_{2}$ wagging (585 and $\left.661 \mathrm{~cm}^{-1}\right)$ [43], and $\mathrm{CO}_{2}\left(2358 \mathrm{~cm}^{-1}\right)$ [44]. 
It can be observed that the intensity of the peaks increased with an increase of TEG concentration. Similar peaks were observed for the different TEG concentrations considered, at the exception of $2358 \mathrm{~cm}^{-1}\left(\mathrm{CO}_{2}\right)$, which was absent for both the $2.5 \mathrm{wt} \%$ and $5 \mathrm{wt} \%$ TEG samples milled at ambient temperature, and which can certainly be assigned to atmospheric $\mathrm{CO}_{2}$. When increasing the milling temperature to $\mathrm{T}=160^{\circ} \mathrm{C}$, the same peaks were observed but with increased intensity, except for the $2.5 \mathrm{wt} \%$ TEG sample. Furthermore, low intensity IR bands appeared in the range $\left(1500-1750 \mathrm{~cm}^{-1}\right)$ and $\left(3500-4000 \mathrm{~cm}^{-1}\right)$ which were not present for the samples milled at ambient temperature. These peaks may correspond to byproducts created as a result of the increased milling temperature, and corresponding among others to $\mathrm{CH}_{2}, \mathrm{CH}_{3}$ deformation (1458 $\mathrm{cm}^{-1}$ ) [40]. This latter observation is congruent with the low fusion temperature of PTFE.

Figure 4. Fourier Transform Infra-Red spectroscopy of PTFE/TEG nanocomposites with different TEG mass fraction $(2.5 \mathrm{wt} \%, 5 \mathrm{wt} \%$ and $10 \mathrm{wt} \%)$ for the samples obtained by milling at $\mathrm{T}=23^{\circ} \mathrm{C}$ and $\mathrm{T}=160^{\circ} \mathrm{C}$.

\subsection{Thermal characterization}

\subsubsection{DSC}

The effect of the inclusion of TEG on the thermal behavior of the nanocomposites during heating was examined by DSC. The DSC thermograms are presented on Figure 5, both for the samples milled at $\mathrm{T}=23^{\circ} \mathrm{C}$ and at $\mathrm{T}=160^{\circ} \mathrm{C}$.

For the samples milled at ambient temperature, the curves corresponding to the different TEG loading display a similar behavior. From ambient temperature to $100^{\circ} \mathrm{C}$, the DSC of the $5 \mathrm{wt} \%$ TEG nanocomposite sample is superior to the two other samples. At about $100^{\circ} \mathrm{C}$, a change of behavior occurs between the curves associated with the $5 \mathrm{wt} \%$ TEG and $10 \mathrm{wt} \%$ TEG samples. 
From approximately $100^{\circ} \mathrm{C}$ onwards, the heat flux of the $10 \mathrm{wt} \%$ TEG nanocomposite is significantly higher compared to those of the other two samples. The exothermal is particularly important with the increase of the concentration at $320^{\circ} \mathrm{C}$. The $\mathrm{I}_{2.5} / \mathrm{I}_{10}$ and $\mathrm{I}_{5} / \mathrm{I}_{10}$ ratios are respectively equal to $30 \%$ and $70 \%$. The $2.5 \mathrm{wt} \%$ TEG sample displays a DSC inferior to the other two samples over the whole temperature range. Moreover, the concentration of TEG was found to impact the value of the glass-transition temperature. In fact, for the samples milled at $\mathrm{T}=23^{\circ} \mathrm{C}$, a glass-transition temperature of $195^{\circ} \mathrm{C}$ was observed for $2.5 \mathrm{wt} \%$ and $205^{\circ} \mathrm{C}$ for $5 \mathrm{wt} \%$ TEG, while it reached approximately $208^{\circ} \mathrm{C}$ for $10 \mathrm{wt} \%$ TEG. A similar trend was observed for the samples milled at $\mathrm{T}=160^{\circ} \mathrm{C}$. Thus, the addition of TEG is responsible for an increase of the glass-transition temperature. This indicates that the degradation of the PTFE/TEG nanocomposite occurs at a relatively higher temperature with a greater TEG loading, and confirms the potential of TEG to improve the thermal properties of PTFE.

When the samples undergo milling at $160^{\circ} \mathrm{C}$ during one hour, the concentration of TEG induces as well an increase of the DSC curves and glass-transition temperature. However, a change of behavior is observed for the heat flux curves. In particular, a steep increase of the heat flux is observed for the $10 \mathrm{wt} \%$ TEG sample above the curves of the other two samples, and the intersection between the curves corresponding to $5 \mathrm{wt} \%$ and $10 \mathrm{wt} \%$ which was observed at $100^{\circ} \mathrm{C}$ for the sample milled at ambient temperature totally disappeared. In this case, the $I_{2.5} / I_{10}$ and $I_{5} / I_{10}$ ratios hold the value of $7 \%$ and $50 \%$, respectively. In addition, by comparing the DSC results for the samples milled at $\mathrm{T}=23^{\circ} \mathrm{C}$ and at $\mathrm{T}=160^{\circ} \mathrm{C}$, it can be observed that a higher milling temperature seems to slightly reduce the glass-transition temperature, with values of approximately $190^{\circ} \mathrm{C}$ for $2.5 \mathrm{wt} \%$ TEG, $195^{\circ} \mathrm{C}$ for $5 \mathrm{wt} \% \mathrm{TEG}$ and $200^{\circ} \mathrm{C}$ for $10 \mathrm{wt} \%$ TEG. This result is an indication that milling at a lower temperature would be preferable in order to ensure the best resistance to heat for the TEG/PTFE nanocomposites. 
Figure 5. Differential scanning calorimetric diagrams of PTFE/TEG nanocomposites with different TEG mass fraction $(2.5 \mathrm{wt} \%, 5 \mathrm{wt} \%$ and $10 \mathrm{wt} \%)$ for the samples obtained by milling at $\mathrm{T}=23^{\circ} \mathrm{C}$ and at $\mathrm{T}=160^{\circ} \mathrm{C}$. Heating rate of $10^{\circ} \mathrm{C} / \mathrm{min}$.

\subsubsection{TGA}

The degradation kinetics of the PTFE/TEG nanocomposites were then studied using Thermogravimetric Analysis. The mass reduction versus time obtained from the TGA measurements are presented on Figure 6. The highest temperature for which the samples were tested was $320^{\circ} \mathrm{C}$. The reason for that is that total calcination of the sample occurred at a higher temperature, as found by the authors in a previous work [24]. In the latter work, a DSC analysis of carbon-nanotubes enriched PTFE displayed an intense peak around $330^{\circ} \mathrm{C}$, and became then unusable. Thus, it was not possible to study the residual weight of the different samples in the present study.

For the PTFE/TEG samples obtained by milling at ambient temperature, a very low weight loss was observed for all samples (less than $2 \%$ in all cases), even up to a temperature of $320^{\circ} \mathrm{C}$. For the sample with $2.5 \mathrm{wt} \%$ TEG, a plateau can be observed which indicates an almost constant sample weight. The measured weight loss increased along the TEG concentration for the other samples. For the PTFE/TEG samples milled at $160^{\circ} \mathrm{C}$, the measured weight loss was similarly relatively low over the whole temperature range (less than $2.5 \%$ in all cases). Regarding the impact of TEG loading on the weight loss, the tendency is however inverted compared to the samples milled at ambient temperature. In fact, the curves obtained for $5 \mathrm{wt} \%$ and $10 \mathrm{wt} \%$ TEG are practically identical; which is an indication that similar mechanisms are involved. However, for the sample containing $2.5 \mathrm{wt} \%$ TEG, a decreasing TGA curve can be observed over the whole temperature range, with a significant 
decrease compared to the other two samples beginning from $100^{\circ} \mathrm{C}$ onwards. The higher thermal conductivity observed from the TGA measurements for the samples obtained by milling at $\mathrm{T}=160^{\circ} \mathrm{C}$ compared to the samples milled at $\mathrm{T}=23^{\circ} \mathrm{C}$ can be explained by the greater dispersion of the EG nanofiller inside of the polymer matrix which was already observed during the structural analysis. Thus, the impact of the TEG concentration on the thermal properties of the PTFE/TEG nanocomposite could be clearly observed as well as the influence of the temperature during milling. For the samples milled at a temperature of $160^{\circ} \mathrm{C}$, the addition of TEG allowed to reduce the thermal degradation of the polymer nanocomposite. This phenomenon was further emphasized by an increase of the concentration of nanofiller. Finally, a concentration of $2.5 \mathrm{wt} \%$ TEG appeared to give the best thermal performance for the samples milled at ambient temperature.

Figure 6. Weight loss versus temperature for the PTFE/TEG nanocomposites (heating rate of $10^{\circ} \mathrm{C} / \mathrm{min}$ ) for $2.5 \mathrm{wt} \%, 5 \mathrm{wt} \%$ and $10 \mathrm{wt} \% \mathrm{TEG}$; samples obtained by milling at $\mathrm{T}=23^{\circ} \mathrm{C}$ and by milling at $\mathrm{T}=160^{\circ} \mathrm{C}$.

\section{Conclusion}

A mobile apparatus was conceived for the production of Thermally-Expanded Graphite (TEG), and TEG-reinforced polytetrafluoroethylene (PTFE) nanocomposites were prepared by manual milling. The obtained samples were then characterized in terms of structural and thermal properties. The XRD results revealed that an acceptable dispersion of the TEG nanofiller inside of the polymer matrix was obtained, and that increasing the temperature during milling enhanced the TEG dispersion compared to milling at ambient temperature.

Furthermore, the DSC measurements gave indications of a relationship between the glasstransition temperature and the concentration of TEG in the samples; an increased 
concentration of TEG leading to a higher glass-transition temperature. However, a higher milling temperature seemed to slightly reduce the glass-transition temperature, which indicates that milling at a lower temperature would allow to ensure the best behavior regarding thermal degradation for the PTFE/TEG nanocomposites. The influence of the TEG loading on the thermal properties of the PTFE/TEG nanocomposite was further studied with TGA. The thermal performance was found to vary depending on the temperature during milling. For the samples milled at a temperature of $160^{\circ} \mathrm{C}$, the addition of TEG allows to reduce the thermal degradation of the polymer nanocomposite, and even more so when the concentration of nanofiller increases. However, a concentration of $2.5 \mathrm{wt} \%$ TEG and milling at ambient temperature gave the best thermal performance for the samples. Thus, the milling temperature should be chosen accordingly to the desired application for the PTFE/TEG nanocomposites. The present work could be further extended in order to assess the potential of TEG to improve the properties of PTFE, for instance in terms of mechanical and electrical properties.

\section{Acknowledgments}

The present work has been carried out in the context of the PNR research project, funded by the Algerian General Directorate for Scientific Research and Technological Development (DG-RSDT), who is gratefully acknowledged.

\section{References}

[1] Schadler, L. S., Brinson, L. C., \& Sawyer, W. G. (2007). Polymer nanocomposites: a small part of the story. Jom, 59(3), 53-60. 
[2] El Achaby, M., Arrakhiz, F. E., Vaudreuil, S., el Kacem Qaiss, A., Bousmina, M., \& Fassi-Fehri, O. (2012). Mechanical, thermal, and rheological properties of graphene-based polypropylene nanocomposites prepared by melt mixing. Polymer Composites, 33(5), 733744.

[3] Yakovlev, A. V., Finaenov, A. I., Zabud'kov, S. L., \& Yakovleva, E. V. (2006). Thermally expanded graphite: synthesis, properties, and prospects for use. Russian journal of applied chemistry, 79(11), 1741-1751.

[4] Gupta, S., He, W. D., \& Tai, N. H. (2016). A comparative study on superhydrophobic sponges and their application as fluid channel for continuous separation of oils and organic solvents from water. Composites Part B: Engineering, 101, 99-106.

[5] Lutfullin, M. A., Shornikova, O. N., Vasiliev, A. V., Pokholok, K. V., Osadchaya, V. A., Saidaminov, M. I., ... \& Avdeev, V. V. (2014). Petroleum products and water sorption by expanded graphite enhanced with magnetic iron phases. Carbon, 66, 417-425.

[6] Ding, X., Wang, R., Zhang, X., Zhang, Y., Deng, S., Shen, F., ... \& Wang, L. (2014). A new magnetic expanded graphite for removal of oil leakage. Marine pollution bulletin, 81(1), 185-190.

[7] Dedov, A. V. (2005). Kinetics of sorption of petroleum products from the surface of water by thermally expanded graphite. Chemistry and technology of fuels and oils, 41(6), 496-498. 
[8] Yakovlev, A. V., Finaenov, A. I., Yakovleva, E. V., \& Finaenova, E. V. (2004). Use of thermally expanded graphite in water-purification and water-treatment systems. Russian journal of applied chemistry, 77(11), 1815-1817.

[9] Sobolciak, P., Karkri, M., Al-Maadeed, M. A., \& Krupa, I. (2016). Thermal characterization of phase change materials based on linear low-density polyethylene, paraffin wax and expanded graphite. Renewable Energy, 88, 372-382.

[10] Tian, H., Wang, W., Ding, J., Wei, X., \& Huang, C. (2016). Preparation of binary eutectic chloride/expanded graphite as high-temperature thermal energy storage materials. Solar Energy Materials and Solar Cells, 149, 187-194.

[11] Yu, H., Gao, J., Chen, Y., \& Zhao, Y. (2016). Preparation and properties of stearic acid/expanded graphite composite phase change material for low-temperature solar thermal application. Journal of Thermal Analysis and Calorimetry, 124(1), 87-92.

[12] Mochane, M. J., \& Luyt, A. S. (2015). The effect of expanded graphite on the flammability and thermal conductivity properties of phase change material based on $\mathrm{PP} / \mathrm{wax}$ blends. Polymer Bulletin, 72(9), 2263-2283.

[13] Fan, L. W., Fang, X., Wang, X., Zeng, Y., Xiao, Y. Q., Yu, Z. T., ... \& Cen, K. F. (2013). Effects of various carbon nanofillers on the thermal conductivity and energy storage properties of paraffin-based nanocomposite phase change materials. Applied energy, 110, $163-172$ 
[14] Meng, F., Huang, F., Guo, Y., Chen, J., Chen, X., Hui, D., \& Zhou, Z. (2017). In situ intercalation polymerization approach to polyamide-6/graphite nanoflakes for enhanced thermal conductivity. Composites Part B: Engineering, 117, 165-173.

[15] Kuester, S., Merlini, C., Barra, G. M., Ferreira, J. C., Lucas, A., de Souza, A. C., \& Soares, B. G. (2016). Processing and characterization of conductive composites based on poly (styrene-b-ethylene-ran-butylene-b-styrene)(SEBS) and carbon additives: A comparative study of expanded graphite and carbon black. Composites Part B: Engineering, 84, 236-247. [16] Huang, Y. G., Lin, X. L., Zhang, X. H., Pan, Q. C., Yan, Z. X., Wang, H. Q., ... \& Li, Q. Y. (2015).Fe 3 C@ carbon nanocapsules/expanded graphite as anode materials for lithium ion batteries. Electrochimica Acta, 178, 468-475.

[17] Wen, Y., He, K., Zhu, Y., Han, F., Xu, Y., Matsuda, I., ... \& Wang, C. (2014). Expanded graphite as superior anode for sodium-ion batteries. Nature communications, 5 .

[18] Wang, J., Wu, M., Li, Y., Luo, F., Chen, F., Chai, S., \& Fu, Q. (2013). Preparation of expanded graphite/poly (phenylene sulfide) composites with high thermal and electrical conductivity by rotating solid-state premixing and melt processing. Journal of Materials Science, 48(5), 1932-1939.

[19] Dursun, B., Yaren, F., Unveroglu, B., Yazici, S., \& Dundar, F. (2014). Expanded graphite-epoxy-flexible silica composite bipolar plates for PEM fuel cells. Fuel cells, 14(6), $862-867$ 
[20] Du, L. (2008). Highly conductive epoxy/graphite polymer composite bipolar plates in proton exchange membrane (PEM) fuel cells (Doctoral dissertation, University of Akron).

[21] Show, Y., \& Takahashi, K. (2009). Stainless steel bipolar plate coated with carbon nanotube $(\mathrm{CNT}) /$ polytetrafluoroethylene (PTFE) composite film for proton exchange membrane fuel cell (PEMFC). Journal of Power Sources, 190(2), 322-325.

[22] Kang, W. S., Rhee, K. Y., \& Park, S. J. (2016). Thermal, impact and toughness behaviors of expanded graphite/graphite oxide-filled epoxy composites. Composites Part B: Engineering, 94, 238-244.

[23] Gantayat, S., Prusty, G., Rout, D. R., \& Swain, S. K. (2015). Expanded graphite as a filler for epoxy matrix composites to improve their thermal, mechanical and electrical properties. New Carbon Materials, 30(5), 432-437.

[24] Revo, S., Alekseev, A., Ivanenko, E., Labii, T., Boubertakh, A., \& Hamamda, S. (2014). Structure, tribotechnical, and thermophysical characteristics of the fluoroplastic carbonnanotubes material. Nanoscale research letters, 9(1), 1.

[25] Haghighi, A. H., Sheydaei, M., Allahbakhsh, A., Ghatarband, M., \& Hosseini, F. S. (2014). Thermal performance of poly (ethylene disulfide)/expanded graphite nanocomposites. Journal of Thermal Analysis and Calorimetry, 117(2), 525-535.

[26] Gogoi, P., Boruah, M., Bora, C., \& Dolui, S. K. (2014). Jatropha curcas oil based alkyd/epoxy resin/expanded graphite (EG) reinforced bio-composite: Evaluation of the 
thermal, mechanical and flame retardancy properties. Progress in Organic Coatings, 77(1), 8793.

[27] Dittrich, B., Wartig, K. A., Hofmann, D., Mülhaupt, R., \& Schartel, B. (2013). Carbon black, multiwall carbon nanotubes, expanded graphite and functionalized graphene flame retarded polypropylene nanocomposites. Polymers for Advanced Technologies, 24(10), 916926.

[28] Paszkiewicz, S., Nachman, M., Szymczyk, A., Špitalský, Z., Mosnáček, J., \& Rosłaniec, Z. (2014). Influence of expanded graphite (EG) and graphene oxide (GO) on physical properties of PET based nanocomposites. Polish Journal of Chemical Technology, 16(4), 4550.

[29] Kandanur, S. S., Schrameyer, M. A., Jung, K. F., Makowiec, M. E., Bhargava, S., \& Blanchet, T. A. (2014). Effect of activated carbon and various other nanoparticle fillers on PTFE wear. Tribology Transactions, 57(5), 821-830.

[30] Sujuan, Y., \& Xingrong, Z. (2014). Tribological properties of PTFE and PTFE composites at different temperatures. Tribology Transactions, 57(3), 382-386.

[31] Yan, Y., Jia, Z., \& Yang, Y. (2011). Preparation and mechanical properties of PTFE/nano-EG composites reinforced with nanoparticles. Procedia Environmental Sciences, $10,929-935$. 
[32] Burris, D. L., Santos, K., Lewis, S. L., Liu, X., Perry, S. S., Blanchet, T. A., ... \& Sawyer, W. G. (2008). Polytetrafluoroethylene matrix nanocomposites for tribological applications. Tribology of polymeric nanocomposites, 55, 403-38.

[33] Lee, J. Y., Lim, D. P., \& Lim, D. S. (2007). Tribological behavior of PTFE nanocomposite films reinforced with carbon nanoparticles. Composites Part B: Engineering, $38(7), 810-816$.

[34] Xiang, D., Li, K., Shu, W., \& Xu, Z. (2007). On the tribological properties of PTFE filled with alumina nanoparticles and graphite. Journal of reinforced plastics and composites, 26(3), 331-339.

[35] Avramenko T.G., Maksimova G.A., Ivanenko E.A., Shevchenko I.P., Revo S.L. (2015). Effect of structural and morphological features of a nanocarbon component on electrophysical properties of fluoroplastic composite materials. Surface Engineering and Applied Electrochemistry, 51 (6), 509-516.

[36] Dovbeshko, G.I., Kopan, V.S., Revo, S.L., Nishchenko, M.M., Prikhod'ko, G.P., Pyatkovs'ky, M.L., Sementsov, Yu.I., Westermayer, M. (2005) Nanostructure of exfoliated graphite. Metallofizika i Noveishie Tekhnologii, 27(3), 1001-1010.

[37] Kim, S., \& Drzal, L. T. (2009). High latent heat storage and high thermal conductive phase change materials using exfoliated graphite nanoplatelets. Solar Energy Materials and Solar Cells, 93(1), 136-142. 
[38] Zhang, P., Wang, C., \& Wang, R. (2007). Composite reactive block for heat transformer system and improvement of system performance. Journal of Chemical Engineering of Japan, 40(13), 1275-1280.

[39] Patterson, A. L. (1939). The Scherrer formula for X-ray particle size determination. Physical review, 56(10), 978.

[40] Mihály, J., Sterkel, S., Ortner, H. M., Kocsis, L., Hajba, L., Furdyga, É., \& Mink, J. (2006). FTIR and FT-Raman spectroscopic study on polymer based high pressure digestion vessels. Croatica chemica acta, 79(3), 497-501.

[41] Mossoba, M. M., Yurawecz, M. P., \& McDonald, R. E. (1996). Rapid determination of the totaltrans content of neat hydrogenated oils by attenuated total reflection spectroscopy. Journal of the American Oil Chemists' Society, 73(8), 1003-1009.

[42] Qian, Y., Chi, L., Zhou, W., Yu, Z., Zhang, Z., Zhang, Z., \& Jiang, Z. (2016). Fabrication of $\mathrm{TiO} 2$-modified polytetrafluoroethylene ultrafiltration membranes via plasmaenhanced surface graft pretreatment. Applied Surface Science, 360, 749-757.

[43] Liang, C. Y., \& Krimm, S. (1956). Infrared spectra of high polymers. III. Polytetrafluoroethylene and polychlorotrifluoroethylene. The Journal of Chemical Physics, 25(3), 563-571.

[44] Shi, L., \& Gunasekaran, S. (2008). Preparation of pectin-ZnO nanocomposite. Nanoscale research letters, 3(12), 491-495. 